Online: http://journal.uny.ac.id/index.php/jppfa

\title{
REVITALISASI PERAN BAHASA ARAB UNTUK MENGATASI KONFLIK DALAM PERSPEKTIF MULTIKULTURAL
}

\author{
Rohmatun Lukluk Isnaini \\ Universitas Islam Negeri Sunan Kalijaga Yogyakarta \\ Jl. Laksda Adisucipto, Papringan, Caturtunggal, Depok, Sleman, Yogyakarta 55281, Indonesia \\ Email: lukluk_isnaini@yahoo.com
}

\begin{abstract}
Abstrak
Tulisan ini bermaksud menghadirkan kembali peran bahasa Arab sebagai bahasa yang dapat mempersatukan umat. Dalam penelitian ini diketahui adanya disfungsi peran bahasa Arab sebagai bahasa internasional Perserikatan Bangsa-Bangsa dan bahasa resmi 25 negara di benua AsiaAfrika. Bahasa Arab tidak dapat menjembatani berbagai konflik diantara negara-negara Arab yang dikenal sebagai masyarakat multikultural. Melalui penelitian kualitatif yang bersifat studi literatur dapat digambarkan secara jelas, objektif, sistematis, analitis dan kritis untuk melakukan revitalisasi peran bahasa Arab. Hasil penelitian menunjukkan bahwa peran bahasa Arab perlu direvitalisasi melalui perspektif multikultural untuk mengatasi konflik berkepanjangan di negara-negara Arab. Berikut adalah beberapa tahapan revitalisasi peran bahasa Arab untuk mengatasi konflik dalam perspektif multikultural; 1) menegaskan kembali tentang urgensi bahasa Arab sebagai bahasa Agama Islam yang mempunyai substansi penting dalam mengajarkan nilai-nilai kebaikan terutama tentang kesadaran multikultural yang termaktub dalam Alquran dan sunnah;2) mendeklarasikan kembali tentang posisi bahasa Arab sebagai bahasa resmi negara yang harus digunakan sesuai dengan ketentuan bahasa Arab fusha secara massif dan konsekuen; 3) memperkuat komitmen berbahasa Arab dengan baik dan benar dalam berkomunikasi yang disesuaikan dengan etika dan moral; 4) mengutamakan penggunaan bahasa Arab dalam berbagai forum pendidikan dan pemerintahan tanpa mengesampingkan penggunaan bahasa asing Inggris atau Perancis; 5) menggunakan bahasa Arab fusha secara lisan maupun tulisan agar meminimalisir penggunaan bahasa Arab 'amiyyah yang berbeda dari suatu negara dan antar negara.
\end{abstract}

Kata kunci: Peran bahasa Arab, revitalisasi, multikultural

\section{REVITALISASI PERAN BAHASA ARAB UNTUK MENGATASI KONFLIK DALAM PERSPEKTIF MULTIKULTURAL}

\begin{abstract}
This paper intends to bring back the role of Arabic as a language that can unite the people. In this study, there was a dysfunction of the role of Arabic as the international language of the United Nations and the official language of 25 countries in the Asia-Africa continent. Arabic cannot bridge various conflicts between Arab countries known as multicultural societies. Through qualitative research with the character of literature, it can be described clearly, objectively, systematically, analytically and critically to revitalize the role of Arabic. The results of the study show that the role of Arabic language needs to be revitalized through a multicultural perspective to overcome prolonged conflicts in Arab countries. The following are some stages of revitalizing the role of Arabic to overcome conflicts in a multicultural perspective; 1) reaffirming the urgency of Arabic as the language of Islam that has important substance in teaching good values, especially about multicultural awareness embodied in the Qur'an and the sunnah;2) re-declare the position of Arabic as the official language of the country that must be used in accordance with the provisions of the Arabic language in a massive and consistent manner; 3) strengthen the commitment in Arabic properly and correctly in communicating in accordance with ethics and morals; 4) prioritizing the use of Arabic in various educational and government forums without prejudice to the use of English or French foreign languages; 5) using Arabic fusha both verbally and in writing to minimize the use of Arabic 'amiyyah which is different from one country and between countries.
\end{abstract}

Keywords: The role of Arabic, revitalization, multicultural 


\section{PENDAHULUAN}

Banyak kekhususan yang dimiliki bahasa Arab dibandingkan dengan bahasa-bahasa lain di dunia. Selain sebagai bahasa yang tertulis dalam kitab suci Alquran dan Hadits rasul, Bahasa Arab merupakan salah satu bahasa dari rumpun Semit (usrah al-Lughât al-Sâmiyyah) yang dinilai sebagai bahasa paling tua dan tetap eksis hingga zaman sekarang. Bahasa Arab juga memiliki posisi strategis sebagai bahasa warisan sosial budaya (lughah al-turâts) karena menjadi bahasa nasional di berbagai negara di timur tengah dan sebagian dari benua Afrika. Sehingga bahasa Arab juga termasuk dalam bahasa resmi Perserikatan Bangsa-Bangsa (PBB).

Islam dan budaya Arab (termasuk bahasa Arab) merupakan suatu kesatuan prinsip yang tidak dapat dipisahkan.(Boullata, 2001) Islam merupakan esensi utama dalam budaya Arab. Demikian pula Arab memiliki tempat yang khas dalam Islam. Kebudayaan Arab mempengaruhi beberapa tradisi Islam. Kebudayaan Arab merupakan hasil dari waktu dan tempat tertentu, sementara Islam merupakan kebudayaan yang melintasi wilayah dan waktu bahkan sebagai agama yang universal.(Wekke, 2017b) Tidak dapat dipungkiri pula bahwa bahasa Arab merupakan produk dan subsistem budaya. Bahasa Arab mempunyai dimensi linguistik, humanistik, sosio-kultural, dan pragmatik. Bahasa Arab pada dasarnya mengikuti sistem linguistik yang telah menjadi kesepakatan penutur bahasa ini (nâthiq bi al-'Arabiy$y a h$ ), baik sistem fonologi, leksikologi, morfologi, sintaksis maupun semantik.

Bahasa Arab hidup di masyarakat multikultural di negara-negara perang di Timur Tengah. Sebagai gambarannya, masih banyak negara-negara yang terjebak pada konflik perang saudara, pertumpahan darah, dan pelanggaran hak asasi manusia adalah negara-negara yang berafiliasi dengan bahasa Arab. Dunia Arab tidak pernah berhenti dalam ketegangan perang saudara, dari Suriah hingga Irak, Libya, Yaman dan Somalia dan sebelumnya, Lebanon, Sudan dan Aljazair. Perang di negara-negara tersebut hanya sejenak berakhir kemudian kembali berkecamuk. Contoh paling ekstrim dari fenomena ini adalah perang saudara berkepanjangan di Lebanon.

Seharusnya bahasa Arab sebagai bagian dari unsur budaya dapat berperan dalam mempersatukan bangsa-bangsa dan kunci po- kok dalam mengatasi berbagai konflik. Inti dari bahasa sebagai alat komunikasi dapat dijadikan sebagai penghubung atau jembatan dari segala bentuk kesalahpahaman dalam interaksi sosial kemasyarakatan. Imam Asy-Syafi'i mengatakan, "manusia menjadi buta agama, bodoh dan selalu berselisih paham lantaran mereka meninggalkan bahasa Arab, dan lebih mengutamakan konsep Aristoteles." Apakah benar munculnya konflik yang terjadi dinegara-negara Arab itu karena banyak negara Arab meninggalkan bahasa Arab?

Dari tulisan Muhbib Abdul Wahab menjelaskan bahwa terdapat 5 peran bahasa Arab dalam pengembangan ilmu dan peradaban Islam (Wahab, 2014) Pertama, bahasa Arab berperan sebagai bahasa integrasi. Sejarah menunjukkan bahwa mayoritas bangsabangsa yang ditaklukkan Islam semula bukan berbahasa Arab. Akan tetapi, dalam perkembangannya warga masyarakat yang baru dibebaskan oleh penguasa Islam ini, bahasa Arab mampu menyatukan banyak suku bangsa dan budaya.

Kedua, bahasa Arab berperan sebagai bahasa konservasi. Ketika Islam berkembang ke luar Jazirah Arabia, kebutuhan umat Islam untuk dapat mengakses dan memahami sumber ajaran Islam (al-Qur'an) tentu semakin mendesak. Ketiga, bahasa Arab berperan sebagai bahasa edukasi dan studi. Ketika Islam mencapai kemajuannya, bahasa Arab kemudian memainkan peran sebagai bahasa pendidikan, pembelajaran dan penelitian ilmiah di hampir semua lapisan masyarakat Arab sehingga bahasa Arab kemudian menjadi bahasa ilmu pengetahuan dan teknologi.

Keempat, bahasa Arab berperan sebagai bahasa komunikasi lintas suku bangsa dan generasi yang mempercepat proses transmisi nilai-nilai Islam dan nilai-nilai sosial kemanusiaan di kalangan masyarakat Arab. Seperti karakter bangsa Arab pada umumnya, bahasa Arab merupakan bahasa yang terbuka. Bahasa Arab sejak awal memperlihatkan kemampuannya beradaptasi dan menerima perubahan, termasuk mengadopsi bahasa-bahasa Asing. Kelima, bahasa Arab berperan sebagai bahasa standarisasi di bidang ilmu-ilmu keislaman dan lainnya. Hal ini terbukti dengan dirintiskan penulisan kamus bahasa Arab.

Idealnya, bahasa Arab yang menjadi bahasa nasional pada 25 negara, dapat berposisi sebagai bahasa pemersatu bangsa-bangsa 
Arab. Bahasa yang mempunyai andil dalam meredakan konflik pada negara yang masih perang saat ini. Bukan hanya konflik perang pada intern di sebuah negara saja, tetapi juga konflik yang terjadi antar negara Arab. Bahasa sebagai salah satu unsur budaya harus menunjukkan peranannya dalam kajian budaya yang beragam. Menyadarkan bangsa Arab bahwa masyarakatnya terbentuk dari berbagai suku yang memiliki variasi geografi dan variasi lapisan sosial.

Jika dilihat dari peran bahasa Arab yang pertama bahwa bahasa Arab mampu menyatukan banyak suku bangsa dan budaya, perkembangan terakhir menunjukkan bahwa keragaman budaya justru menjadi sumber pertentangan antarkomponen bangsa. Keberagaman budaya di Arab dapat menimbulkan berbagai persolan yang dihadapi bangsa-bangsa Arab saat ini. Korupsi, kolusi, nepotisme, premanisme, perseteruan politik, kemiskinan, kekerasan, saparatisme, perusakan lingkungan dan hilangnya rasa kemanusiaan (konflik perang), merupakan bentuk nyata sebagai bagian dari fenomena multikultural (Raharja, 2010, p. 28).

Disfungsi peran bahasa Arab masih menjadi fenomena dalam kehidupan masyarakat Arab. Salah satunya disebabkan karena tidak dijadikannya bahasa Arab sebagai bagian dari budaya yang dominan untuk mewarnai kehidupan umat Islam di tingkat pribadi, keluarga, dan masyarakat. Di sisi lain, bahasa Arab juga perlu dipandang sebagai bahasa agama dan bukan hanya dipandang sebagai bahasa budaya, etnis, kawasan, maupun negara tertentu saja. Itu ditandai dengan banyaknya tokoh dan ulama muslim yang berasal dari bukan kawasan Arab namun menguasai bahasa Arab sebagai bagian dari studi Islam yang ditekuninya, semisal Al-Ghazali, Al-Biruni, Ibnu Sina, Al-Razi, Al-Kindi.

Secara kultural, ada upaya pula yang ingin diterapkan dan disebarluaskan di kalangan masyarakat Arab, yaitu pemopuleran penggunaan bahasa Arab kolokial (dialek lokal) dan pengesampingan penggunaan bahasa Arab standar (fusha). Hal itu berakibat pada minimnya pengetahuan dan pemahaman masyarakat Arab sendiri terhadap bahasa Arab yang resmi dan standar. Dengan demikian sekat-sekat perpecahan bisa timbul dari kesalahpahaman komunikasi dengan penggunaan bahasa Arab yang tidak lagi bahasa Arab fusha. Tidak hanya dari tiap negara memiliki bahasa Arab 'amiyah sendiri, namun setiap etnis bisa memiliki bahasa Arab yang berbeda-beda logatnya. (Anonim, 2013)

Fakta tentang konflik kebahasaan karena perbedaan logat atau dialek terjadi di negara Yordania. Terdapat dua artikulasi dialek secara nasional, dialek Amman sebagai pengucapan di wilayah ibukota. Secara sosial dianggap sebagai dialek dengan stratifikasi yang tinggi. Sementara penutur dialek Baduwi dengan jumlah lebih besar justru dianggap sebagai dialek yang rendah. Variasi lainnya adalah penutur bahasa Arab yang berasal dari Tepi Barat. Mereka mengungsi saat terjadinya konflik kemudian memilih untuk mencari pekerjaan di Tepi Timur. Terdapat stereotype dalam urusan dialek tersebut sehingga menimbulkan ketersinggungan. Bagi penutur dengan dialek Baduwi, mereka menganggap bahwa dialek yang digunakannya menunjukkan keindahan dan maskulinitas. Sehingga bagi penutur dialek lainnya justru dianggap sebaliknya. Termasuk akses pendidikan diantara keduanya yang jauh berbeda, sehingga satu sama lain saling mempersepsikan kondisi yang sesungguhnya tidak berkaitan langsung dengan bahasa itu sendiri. Keadaan seperti itu yang menjadikan perjumpaan para penutur menimbulkan relasi yang tidak nyaman sehingga menimbulkan perselisihan (Wekke, 2017a).

Bahasa Arab yang awalnya dimanipulasi menjadi bagian dari politik, kebudayaan, dan bahkan juga perbedaan sejarah, sebenarnya bisa menjadi instrumen baik dalam meredam konflik dan merintis perdamaian untuk memulai perundingan diantara kedua pihak yang berkonflik. Misalnya, konflik Yordania dan Palestina di tahun 1994, kosakata yang digunakan bertambah seiring dengan ketegangan diantara kedua negara. Bahasa di media dan kurikulum sekolah memaknai peristiwa yang terjadi sehingga memperkaya kosakata. Begitu juga dengan usaha untuk mengurangi ketegangan antara Palestina dan Israel disepakati dalam pertemuan Oslo pada tahun 1993 untuk saling menggunakan istilah bahasa yang sudah wujud diantara kedua bangsa. Sebab jika keduanya bisa saling menerima justru merupakan kesempatan untuk saling mengenal dan memperkaya cakrawala kebahasaan. Sehingga tidak membatasi diri pada dialek yang dituturkan semata.

Berdasarkan pada konsep pendidikan multikultural, tulisan yang belum banyak dika- 
ji ini mencoba untuk meninjau ulang peran bahasa Arab di era modern saat ini sebagai bahasa pemersatu bangsa Arab dalam mendamaikan konflik negara-negara pemilik bahasa Arab. Hal ini dapat dilakukan melalui penetapan untuk memilih suatu asas yang disesuaikan dengan realitas masing-masing bangsa. Realitas suatu bangsa yang menunjukkan adanya kondisi keanekaragaman budaya dalam mengarahkan pada pilihan untuk menganut asas multikulturalisme. Dalam asas multikulturalisme ada kesadaran bahwa bangsa itu tidak tunggal, tetapi terdiri atas banyak komponen yang berbeda. Multikulturalisme menekankan prinsip tidak ada kebudayaan yang tinggi, dan tidak ada kebudayaan yang rendah di antara keragaman budaya tersebut. Semua kebudayaan pada prinsipnya sama-sama ada.

\section{METODE PENELITIAN}

Jenis penelitian ini adalah penelitian kualitatif. Yaitu penelitian yang menghasilkan informasi berupa catatan dan data deskriptif yang terdapat di dalam teks yang diteliti (Mantra, 2008, p. 30). Pendekatannya menggunakan pendekatan studi literatur (literature review) atau studi pustaka (library research). Library research menggunakan buku-buku dan literatur-literatur lainnya sebagai objek yang utama (Sutardi, 2007, p. 76). Dengan penelitian kualitatif, perlu dilakukan analisis deskriptif. Metode analisis deskriptif memberikan gambaran dan keterangan yang secara jelas, objektif, sistematis, analitis dan kritis mengenai Revitalisasi Peran Bahasa Arab untuk Mengatasi Konflik dalam Perspektif Multikultural.

Metode yang digunakan dalam penelitian kepustakaan adalah mengumpulkan data penelitian berupa data-data kepustakaan yang telah dipilih, dicari, disajikan dan dianalisis. Sumber data penelitian ini mencari data-data kepustakaan yang substansinya membutuhkan tindakan pengolahan secara filosofis dan teoritis. Studi pustaka di sini adalah studi pustaka tanpa disertai uji empirik (Muhadjir, 1998, p. 159) Data yang disajikan adalah data yang berbentuk kata yang memerlukan pengolahan supaya ringkas dan sistematis. (Muhadjir, 1998) Pengumpulan data yang dilakukan dalam penelitian ini adalah dengan mengumpulkan bukubuku tentang bahasa Arab dan konsep multikultural. Kemudian dipilih, disajikan dan dianalisis serta diolah secara sistematis.

\section{HASIL PENELITIAN DAN PEMBAHASAN}

\section{Bahasa dari Unsur Budaya}

Unsur-unsur kebudayaan menurut Koentjaraningrat (2009, p. 186) adalah: pertama bahasa dan komunikasi, kedua ilmu pengetahuan, ketiga teknologi, keempat ekonomi, kelima organisasi sosial, keenam agama, dan ketujuh kesenian. Pertama yang disebutkan dari unsur budaya yaitu bahasa. Deskripsi bahasa dalam kajian budaya mefokuskan perhatian pada ciri-ciri yang menonjol seperti daerah persebaran, variasi geografi, dan variasi lapisan sosial (tingkat sosial bahasa atau social levels of speech).

Terdapat kajian dalam antropologi yang khusus mempelajari tentang persebaran bahasa lokal suatu kebudayaan. Kajian tersebut dinamakan antropologi linguistik. Selain mempelajari bahasa-bahasa berbagai suku bangsa, antropologi linguistik juga mengkaji sejarah munculnya bahasa, berbagai struktur dan berbagai jenis bahasa, keanekaragaman, perseberaan bahasa di permukaan bumi. Hubungan kajian mengenai bahasa lokal dengan etnografi adalah bahwa bahan-bahan linguistik yang berupa daftar kata gambaran diri, dan tata bahasa lokal yang tersebar diberbagai tempat, terkumpul bersama bahan-bahan etnografi. Dari bahan ini kemudian berkembang berbagai metode analisis bahasa serta berbagai hubungan antara bahasa dan kebudayaan. Namun, tidaklah mudah mempelajari persebaran suatu bahasa suku bangsa karena di daerah perbatasan hubungan antara dua suku bangsa yang tinggal berdekatan umumnya sangat intensif sehingga terjadi saling mempengaruhi dalam bahasa (Sutardi, 2007, p. 77).

Bahasa pada suatu bangsa yang relatif besar dengan jumlah beberapa juta penutur senantiasa mengalami variasi-variasi yang disebabkan oleh adanya perbedaan wilayah geografis dan adanya perbedaan lapisan serta lingkungan sosial. Sebuah teori diungkapkan oleh ahli linguistik Amerika bernama Edward Saphir dan muridnya Benjamin Lee Whorf yang menyatakan bahwa bahasa menentukan cara berpikir manusia, menentukan cara manusia melihat realitas dunia, membantu manusia dalam melihat dunia dan menyusun strukturnya. Bahasa adalah salah satu alat yang sangat penting dalam mempelajari kebudayaan dan warisan kebudayaan. Bahasa digunakan oleh para anggota masyarakat dengan kebudayaannya masing-masing, yang penggunaannya di- 
pengaruhi oleh variabel-variabel sosial, seperti kelas dan status sosial (Sutardi, 2007).

Keragaman budaya juga dipengaruhi oleh ragam bahasa yang digunakan. Perbedaan geografis suatu daerah ataupun lapisan serta lingkungan sosial sangat berpengaruh terhadap keragaman bahasa. Bahasa merupakan komponen penting budaya. Karena melalui media bahasa inilah semua aspek budaya ditransfer secara lisan maupun tulisan. Sulit untuk memahami nuansa dan makna dalam suatu budaya tanpa memahami bahasanya.

Para ahli mengatakan bahwa kebudayaan menjadi mainsystem, sedangkan bahasa hanya merupakan subsystem, tidak ada atau belum ada yang mengatakan sebaliknya (Mujib, 2009 , p. 145). Berkaitan dengan hubungan yang bersifat koordinatif antara bahasa dengan kebudayaan, Masinambouw (1985) menyebutkan bahwa bahasa dan kebudayaan merupakan dua sistem yang "melekat" pada manusia karena kebudayaan merupakan sistem yang mengatur interaksi manusia, sedangkan bahasa atau kebudayaan merupakan sistem yang berfungsi sebagai sarana keberlangsungan sarana itu (Chaer \& Agustina, 2004, pp. 217-218).

Sistem bahasa mempunyai fungsi sebagai sarana berlangsungnya interaksi manusia di dalam masyarakat, maka berarti di dalam tindak laku berbahasa haruslah disertai normanorma yang berlaku di dalam budaya itu. Sistem tindak laku berbahasa menurut norma-norma budaya disebut etika berbahasa atau tata cara berbahasa. Dalam analisis semantik, Abdul Chaer mengatakan bahwa bahasa itu bersifat unik dan mempunyai hubungan yang sangat erat dengan budaya masyarakat pemakainya, maka analisis suatu bahasa hanya berlaku untuk bahasa itu saja, tidak dapat digunakan untuk menganalisis bahasa lain (Chaer \& Agustina, 2004).

Sebagaimana bahasa Arab yang mempunyai puluhan nama untuk buah kurma mulai dari yang masih di pohon, yang baru dipetik, sampai yang telah kering. Seperti الجر الز الز kurma kering, الرطب kurma matang, الفاخز kurma yang tidak ada isinya, الدمال kurma busuk, dan الترطر kurma (Abusyairi, 2013, p. 174). Beberapa keistimewaan bahasa tersebut dipakai suatu bangsa, atau daerah tertentu untuk membatasi cara-cara berpikir dan pandangan bangsa atau daerah yang bersangkutan terhadap fenomena tempat mereka hidup. Dengan demikian bahasa komunikasi yang baik tidak hanya tertumpu pada penguasaan linguistik semata tetapi mencakup penguasaan untuk memilih bentuk bahasa yang sesuai dengan konteks, sehingga diperlukan pemahaman terhadap budaya penutur yang berlaku disamping penguasaan yang baik terhadap budayanya sendiri.

\section{Konsep dan Prinsip Multikultural}

Multikultural merupakan satu istilah yang populer untuk menggambarkan pendidikan keberagaman (Wekke \& Lubis, 2008, p. 295). Multikultural dianggap sebagai sebuah pandangan yang berusaha mengakses eksistensi pluralitas agama, budaya, bahasa, etnis, sistem sosial, dan keanekaragaman lainnya. Cara pandang ini dilatarbelakangi munculnya sikap diskriminatif dan ketidakadilan sekelompok orang terhadap sekelompok orang lainnya. Studi khusus tentang pendidikan multicultural ini bertujuan untuk membangun sikap toleran, pluralis, dan humanis terhadap masing-masing entitas manusia.

Wacana demokratisasi, humanisme, inklusifisme dan pluralisme, beserta derifasinya, semakin gencar diperbincangkan sebagai isu sentral-global, maka kajian yang mengangkat tema pendidikan multikultural dalam multi perspektif, seperti filosofis, sosiologis, psikologis, politis, antropologis, teologis dan seterusnya, menjadi sangat menarik dan urgen dikritisi. Paling tidak ada empat alasan kenapa masalah ini menjadi begitu menarik diperbincangkan, yaitu: Pertama, trend global yang telah melahirkan budaya posmo cenderung memunculkan pola pikir, pandangan, sikap dan perilaku yang tidak mau dikendalikan oleh satu sistem nilai tertentu, tetapi setiap orang akan mencari dan mengkombinasikan sistem nilai yang menurutnya sesuai dengan harapan. $\mathrm{Ke}$ $d u a$, sebagian besar orang sudah jenuh dengan perselisihan dan konflik yang terjadi dewasa ini, sebagai akibat dari sikap primordialisme, status quo, otoritarianisme, eksklusifisme, dan kesombongan lainnya, masyarakat dewasa ini begitu mendambakan ketenangan, kebersamaan, kesahajaan, inklusif, dan humanis. Ketiga, realitas sosial, budaya, agama, ras, suku, bahasa, dan sebagainya yang demikian plural, mustahil untuk dikesampingkan. Keempat, kemajuan teknologi informasi yang demikian cepat telah membuat dunia semakin sempit dan tanpa batas (Mu'min, 2016, pp. 74-75). 
Konsep pendidikan multikultural, Banks menjelaskan adanya lima dimensi dalam implementasi pendidikan multikultural, yakni: content integration, knowledge construction, equity pedagogy, prejudice reduction, dan empowering school culture (Banks, 2007, pp. 83-85) Dengan demikian, diharapkan tujuan dari pendidikan multikultural dapat dicapai sehingga setiap individu pembelajar akan memiliki sikap dan perilaku yang positif terhadap keberadaan masyarakat yang multikultural.

\section{Karakteristik Bahasa Arab dalam Konteks Universal}

Bahasa Arab memiliki karakteristik yang unik dan universal. Dikatakan unik karena bahasa Arab memiliki ciri khas yang membedakannya dengan bahasa lainnya, sedangkan universal berarti adanya kesamaan nilai antara bahasa Arab dengan bahasa lainnya. Karakteristik universalitas bahasa Arab antara lain (Zaenuddin, 2005, p. 2). Satu, Bahasa Arab memiliki ragam bahasa, yang meliputi, (a) ragam sosial atau sosiolek yaitu ragam bahasa yang menunjukan stratifikasi sosial ekonomi penuturnya; (b) ragam geografis, ragam bahasa yang menunjukan letak geografis penutur antara satu daerah dengan daerah lain, sehingga melahirkan dialek yang beragam; (c) ragam idiolek yaitu ragam bahasa/ dialek yang menunjukan integritas kepribadian setiap individu masyarakat.

Dua, bahasa Arab dapat diekspresikan secara lisan ataupun tulisan. Tiga, bahasa Arab memiliki system, aturan dan perangkat yang tertentu, antara lain: (a) Sistemik, bahasa yang memiliki system standard yang terdiri dari sejumlah sub-sub system (sub system tata bunyi, tata kata, kalimat, syntax, gramatikal, wacana dan sebagainya). (b) Sistematis, artinya bahasa Arab juga memiliki aturan-aturan khusus, dimana masing-masing komponen sub sistem bahasa bekerja secara sinergis dan sesuai dengan fungsinya. (c) Komplit, maksudnya bahasa itu memiliki semua perangkat yang dibutuhkan oleh masyarakat pemakai bahasa itu ketika digunakan untuk sebagai alat komunikasi dalam berinteraksi dan bersosialisasi. Empat, bahasa Arab memiliki sifat yang arbitrer dan simbolis. Arbitrer berarti tidak adanya hubungan rasional antara lambang verbal dengan acuannya. Dengan sifat simbolis yang dimiliki bahasa, manusia dapat meng- abstraksikan berbagai pengalaman dan buah pikirannya tentang berbagai hal.

Lima, bahasa Arab berpotensi untuk berkembang, produktif dan kreatif. Karena perkembangan bahasa selalu mengikuti perkembangan peradaban manusia, sehingga muncul kata dan istilah-istilah bahasa baru yang digunakan untuk mengkomunikasikan ilmu pengetahuan dan teknologi yang terus berkembang. Enam, bahasa Arab merupakan fenomena individu dan fenomena sosial. Sebagai fenomena individu, bahasa merupakan ciri khas kemanusiaan. Bahasa bersifat insani karena hanya manusia yang mempunyai kemampuan berbahasa verbal. Adapun sebagai fenomena sosial, bahasa merupakan konvensi suatu masyarakat pemilik atau pemakai bahasa itu. Seseorang menggunakan bahasa sesuai normanorma yang disepakati atau ditetapkan untuk bahasa tersebut. Kesepakatan yang dimaksudkan pada dasarnya merupakan kebiasaan yang berlangsung turun temurun dari nenek moyang, yang sifatnya mengikat dan harus diikuti oleh semua pengguna bahasa.

\section{Subtansi Bahasa Arab dalam Perspektif Multikultural}

Bahasa Arab adalah bahasa agama Islam. Hal ini dibuktikan bahwa salah satu alasan seseorang mempelajari bahasa Arab karena motivasi religious. Bahasa Arab dipandang mampu untuk mengakomodasi pesan-pesan Ilahi yang universal, tidak hanya untuk umat Islam saja, namun untuk seluruh semesta alam. Islam mengajarkan menghargai keberagaman sebagai sebuah kenyataan yang tidak dapat dielakkan. Dunia diciptakan dengan berbagai macam bentuk, warna, dan corak. Masyarakat terbagi menjadi beragam etnis, suku, ras, agama, dan budaya.

Keistimewaan bahasa Arab sebagai bahasa Agama semestinya dapat mengakomodasi pesan-pesan positif agama Islam yang dapat tertanam dalam diri pribadi setiap muslim. Sebagaimana Islam mengajarkan dalam surat Al-Hujurat ayat 13 bahwa Allah telah menciptakan manusia dari seorang laki-laki dan seorang perempuan, kemudian menjadikannya berbangsa-bangsa dan bersuku-suku agar saling mengenal. Para mufassir kemudian menegaskan bahwa secara substansial ayat ini menerangkan tentang keragaman umat manusia dari berbagai sisi yaitu dari sisi keragaman manusia secara geografis, keragaman 
geo-politik, kultural maupun negara bangsa (nation-state) (Suparman, 2017, p. 186). Berdasarkan hal di atas maka multikultural dapat dipahami sebagai pengakuan bahwa sebuah negara atau masyarakat itu beragam dan majemuk. Sebaliknya tidak ada satu negara pun yang mengandung hanya kebudayaan nasional tunggal. Multikultural harus disadari oleh umat sebagai sunatullah yang tidak dapat ditolak bagi setiap negara dan bangsa di dunia (Baidhawy, 2005, p. 7)

Firman Allah dalam Surat Ar-Ruum ayat 22 menyebutkan bahwa diantara tandatanda kekuasaan-Nya ialah diciptakannya langit dan bumi dan berlain-lainan bahasa dan warna kulit. Di kitab Tafsir Al-Misbah, M. Quraisy Shihab menjelaskan bahwa Alquran demikian menghargai bahasa dan keragamannya, bahkan mengakui penggunaan bahasa lisan yang beragam. Perlu ditegaskan bahwa dalam konteks pembicaraan tentang paham kebangsaan, bahasa pikiran dan bahasa perasaan dinilai jauh lebih penting ketimbang bahasa lisan, sekalipun bukan berarti mengabaikan bahasa lisan, karena sekali lagi ditekankan bahwa bahasa lisan adalah jembatan perasaan. Atas dasar semua itu, Alquran telah mengakui bahwa bahasa sangat urgen untuk dapat dijadikan perekat dan kesatuan umat. Keragaman bahasa di dunia merupakan salah satu bukti keEsaan dan kebesaran Allah (Shihab, 2002, pp. 340-342).

Pada firman Allah surat Hujurat ayat 6 menyarankan kepada umat Islam bahwa ketika menghadapi permasalahan harus selalu mengedepankan klarifikasi, dialog, diskusi, dan musyawarah. Tidak boleh menjatuhkan vonis tanpa mengetahui dengan jelas permasalah-annya (Suparman, 2017). Dalam proses klarifikasi, dialog, diskusi dan musyawarah tersebut dibutuhkan bahasa komunikasi yang efektif dan disesuaikan dengan kode etik dan ketentuan moral. Sehingga tidak memperkeruh permasalahan dan menimbulkan perselisihan, permusuhan, atau bahkan peperangan hanya karena tidak mau menerima perbedaan.

Realitas multikultural juga dijelaskan dalam hadist, yaitu khutbah yang disampaikan oleh Nabi Muhammad SAW pada hari-hari tasyriq: "Wahai manusia, camkanlah (oleh kalian) Sesungguhnya Tuhan kalian satu dan moyang kalian juga satu. Camkanlah (oleh kalian) tidak ada keutamaan bagi orang Arab atas nonArab, begitu juga non-Arab atas Arab, tidak pula orang kulit merah atas orang hitam, maupun orang hitam atas orang berkulit merah kecuali karena (faktor) ketakwaan. Sudahkah aku sampaikan?!” (HR. Ahmad). (Hambal, n.d.)

Substansi bahasa Arab sebagai bahasa dari agama Islam telah mengakomodir konsep multikultural yang dibuktikan dengan dua ayat Al-quran dan satu hadits di atas. Dengan demikian dapat disimpulkan bahwa (1) Islam dalam Al-quran dan hadits menerangkan tentang keragaman manusia dari berbagai sisi; (2) multikultural harus disadari oleh umat sebagai sunatullah yang tidak dapat ditolak bagi setiap negara dan bangsa di dunia; (3) Allah tidak membeda-bedakan umatnya karena perbedaan suku, yang membedakan umat satu dengan yang lainnya adalah tingkat ketak-waannya; (4) Alquran telah mengakui potensi bahasa (bahasa Arab) untuk dapat dijadikan perekat kesatuan umat; (5) Bahasa dapat membentuk realitas dan memiliki fungsi proteksi dan dapat mengubah situasi dari perselisihan menjadi perdamaian.

\section{Peta Negara Penutur Bahasa Arab dan Arab Society Di Negara Lebanon dan Suriah}

Bahasa Arab memiliki lebih banyak penutur daripada bahasa-bahasa lainnya dalam rumpun bahasa Semitik. Bahasa Arab dituturkan oleh lebih dari 280 juta orang sebagai bahasa pertama, yang mana sebagian besar tinggal di Timur Tengah dan Afrika Utara. Bahasa ini adalah bahasa resmi dari 25 negara (Aljazair, Bahrain, Comoros, Djibouti, Mesir, Irak, Jordania, Kuwait, Libanon, Libya, Mauritania, Maroko, Oman, Palestina, Qatar, Saudi Arabia, Somalia, Sudan, Syria, Tunisia, Uni Emirat Arab, Yaman, Sahara Barat, Chad, dan Eritrea) (Saripedia, 2011).

Persebaran penggunaaan bahasa Arab sebagai bahasa resmi dapat dilihat pada peta negara-negara di Timur Tengah dan Afrika Utara yang disajikan pada Gambar 1.

Dari peta pada Gambar 1, selanjutnya sebagai gambaran negara konflik yang berusaha merevitalisasi peran bahasa Arab akan dijelaskan profil 2 negara berikut yang disajikan pada Gambar 1. 


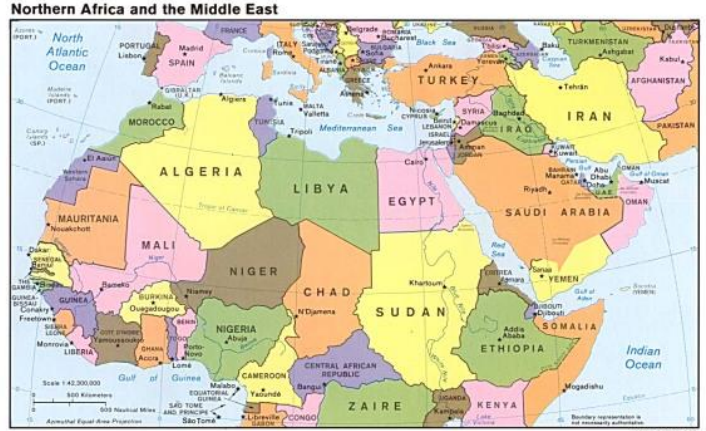

Gambar 1. Peta Negara Penutur Bahasa Arab

\section{Kondisi Sosial Budaya Negara Lebanon}

Lebanon dapat dikatakan sebagai negara multi culture di kawasan Timur Tengah. Hampir sebagian besar peduduknya merupakan perpaduan keturunan Arab dan Eropa (khususnya Perancis). Bentuk pemerintahan adalah Republic of Lebanon dan ibukotanya adalah Beirut. Masyarakat Lebanon pada umumnya secara sosiologis dikategorikan sebagai masyarakat dengan sistem sektarian, terutama berdasar pada sekte keagamaan. Begitu sektariannya, sehingga segala ruang lingkup kehidupan masyarakat Lebanon tak bisa lepas dari sekteisme, baik pada tataran sosial terlebih dalam urusan politik (confessionalism politic).

Warga Lebanon berjumlah kurang lebih 4 juta jiwa, ditambah dengan warga asing lainnya, (imigran/pekerja/pengungsi) kurang lebih 1,5 juta jiwa, seperti warga Syria, Palestina, Armenia, Kurdistan, Mesir, Srilanka, Filipina, Sudan dan negara negara Eropa Timur, Afrika dan negara Arab lainnya. Dari kurang lebih 3.1 juta jiwa (sensus 1999), terdapat 17 aliran agama dengan berbagai sekte dan alirannya, yaitu: 5 Muslim (Syiah, Sunni, Druze, Ismaili dan Alawi); 11 Kristen (4 OrtodoksArmenia, Yunani, Syria, Nestoria-Assyiria; 6 Katolik-Armenia, Syria, Kaldea, Yunani, Romawi, Maronit dan 1 Protestan) dan Yahudi. Pembagian berdasarkan etnis hanya terdiri dari masyarakat Arab, Armenia dan Kurdi. Agama dan politik bagi kehidupan masyarakat Lebanon tidak dapat dipisahkan. Perang saudara yang pernah berkecamuk selama 15 tahun di Lebanon sesungguhnya tidak terlepas dari masalah pertentangan antara etnis pemeluk agama. Sebagai akibatnya, pembagian politik dan kekuasaan, di tingkat grassroot pun, masyarakat secara otomatis membagi wilayah/ distrik- nya berdasarkan agama dan sektenya masingmasing.

Masyarakat Lebanon yang pluralistik merupakan keunikan tersendiri diantara negara Arab. Agama yang dianut mayoritas warga Lebanon menginduk pada dua agama besar yaitu Islam dan Kristen. Namun mereka terbagi dalam sekte yang beragam yang jarang ditemui di negara lain. Mereka misalnya tidak hanya terbatas meyakini Islam beraliran Sunni, tapi juga sekte Shiah, Druze dan Alawite. Demikian pula dengan Kristen, ada yang menganut Kristen Maronite, Katolik, Protestan, Orthodox, Anglican dan Armenian. Bahkan ada yang menganut agama Yahudi meskipun sebagian besar sudah berhijrah ke Israel.(Anonim, n.d.)

Sebagai bahasa resmi di Lebanon, ternyata bahasa Arab tidak memiliki posisi strategis. Bahasa yang sering digunakan adalah bahasa Perancis dan Inggris. Bahasa Perancis biasanya dipakai oleh pejabat pemerintah dan masyarakat menengah ke atas. Bahasa Inggris sudah biasa dipakai terutama dalam bidang bisnis dan pendidikan. Bahasa lainnya adalah bahasa yang dipakai kelompok etnis seperti bahasa Armenia. Persoalan bahasa Arab muncul karena seringnya penggunaan bahasa Perancis dan Inggris daripada bahasa Arab. Seperti kasus ketika Randa Makhoul, guru seni di sekolah di Beirut, bertanya kepada muridnya dalam bahasa Arab, dia sering mendapatkan jawaban dalam bahasa Inggris atau Perancis. Makhoul hanya salah satu dari beberapa guru Lebanon dan orangtua yang peduli dengan peningkatan jumlah anak muda yang tidak menguasai baha Arab, meskipun lahir dan dibesarkan di negara di kawasan Timur Tengah. Dia menyambut kampanye pemerintah untuk menyelamatkan bahasa Arab di Lebanon, yang disebut "Anda bicara dari Timur dan dia menjawab dari Barat". "Kampanye ini bertujuan untuk meningkatkan kepedulian mengenai pentingnya untuk mempertahankan bahasa resmi nasional Lebanon. Dari Kementerian Budaya Lebanon mendorong untuk belajar bahasa asing, tetapi tidak meninggalkan bahasa ibu. Hal ini sungguh menyedihkan karena tidak ada satu pun dari generasi muda Lebanon yang dapat berbicara bahasa Arab dengan baik.

Bahasa Arab merupakan bahasa resmi di Lebanon, tetapi Inggris dan Prancis digunakan secara luas. Sebagian besar orang Lebanon berbicara bahasa Perancis karena menjadi koloni Perancis dan generasi muda beralih 
menggunakan bahasa Inggris. Jumlah orangtua yang mendaftarkan anaknya di Sekolah yang menggunakan kurikulum Perancis, Inggris dan Amerika, dan berharap suatu hari akan membantu mereka untuk mendapatkan pekerjaan dan masa depan yang terjamin. Bahkan, sebagian dari mereka berbicara dengan bahasa Perancis dan Inggris di rumah.

Bahasa Lebanon klasik juga memiliki perbedaan dengan bahasa Arab, dalam dialek dan bahasa. Bahasa klasik hampir tidak pernah digunakan dalam percakapan, hanya digunakan di berita, pidato resmi pejabat, dan sejumlah program televisi. Sekarang, banyak generasi muda Lebanon harus berupaya meningkatkan kemampuan membaca dan menulis dalam bahasa Arab. Kampanye bahasa Arab yang dilakukan pemerintah Lebanon juga dialami sejumlah negara-negara Arab yang banyak memiliki sekolah asing seperti Uni Emirat Arab, Jordania, Mesir dan sebagian negara Afrika Utara. Kampanye bahasa Lebanon merupakan yang pertama diluncurkan oleh pemerintah Arab. Kementerian Budaya mengatur pertemuan di sekolah untuk meningkatkan kepedulian di kalangan siswa mengenai betapa pentingnya mempertahankan bahasa ibu dan mendorong mereka untuk bangga menggunakannya. Mansour, juru bicara kementerian budaya, mengatakan pemerintah berharap melindungi bahasa Arab di Lebanon agar menjaga identitas dan warisan negara (Shawish, 2010)

\section{Negara Suriah}

Suriah merupakan salah satu negara di Timur Tengah yang heterogen. Penduduk Suriah terdiri dari berbagai etnis dan agama. Agama Islam di Suriah terpecah menjadi dua yaitu muslim sunni dan muslim syiah. Muslim sunni di Suriah merupakan penduduk mayoritas dengan jumlah sekitar lebih dari $70 \%$ (Manshur, 2010). Suriah yang terdiri dari ethnoreligious yang berarti kelompok masyarakat yang disatukan berdasarkan kesamaan latar belakang agama yang menegaskan identitas etnis mereka dengan berdasarkan hubungan kekeluargaan atau kesamaan agama kelompok etnoreligious di Suriah dapat dilihat dari kelompok Druze dan Alawi. (Fox, 2002) Populasi di Suriah terbagi menjadi beberapa golongan diantaranya Sunni Arab (kurang lebih $60 \%$ dari populasi), Kristen (sekitar 10-12\%) Alawi yang menganut Syiah sekitar (10- 12\%), Druze (se- kitar 6\%) dan sebagainya. Kebanyakan golongan di Suriah merupakan golongan Sunni, adapun etnis minoritas adalah Kurdi dan Armenians. (Carpenter, 2013)

Dari dulu sampai Sekarang Suriah terbagi menjadi 2 kubu yaitu kubu Sunni dan Syiah dan kedua kubu inilah yang memainkan peranan politik di Suriah, pada tahun 19461963 perpolitikan di Suriah dikuasai oleh Sunni dan kemudian pada tahun 1963-1970 Syiah mulai menyatukan diri untuk merebut kekuasaan dari Sunni hingga kemudian memimpin perpolitikan Syiah dari 1970 hingga 2016. Perpolitikan di Sunni atau Syiah selalu menjadi ajang perebutan kedua belah kubu karena menyangkut hal perbedaan etnis sehingga belum pernah Sunni dan Syiah menjalankan politik Suriah secara bersamaan, yang terjadi adalah Sunni yang menguasai politik atau Syiah yang menguasai politik. Seperti tidak ada satu kepaduan antara Sunni dan Syiah di Suriah.

Bahasa Arab adalah bahasa resmi negara itu. Beberapa dialek Arab modern digunakan dalam kehidupan sehari-hari, terutama Levantine di barat dan Mesopotamian di timur laut. Menurut The Encyclopedia of Arabic Language and Linguistics, selain bahasa Arab, bahasa-bahasa berikut diucapkan di negara ini, dalam urutan jumlah pembicara: Kurdi, Turki, Neo-Aram (empat dialek), Sirkasia, Chechnya, Bahasa Armenia, dan akhirnya bahasa Yunani. Namun, tidak satupun dari bahasa minoritas ini memiliki status resmi.

Bahasa Aram adalah bahasa lingua franca wilayah sebelum munculnya bahasa Arab, dan masih digunakan di kalangan orang Asyur, dan Syriac Klasik masih digunakan sebagai bahasa liturgi berbagai denominasi Kristen Syria. Yang paling luar biasa, NeoAramaik Barat masih diucapkan di desa Ma'loula serta dua desa tetangga, $56 \mathrm{~km}$ timur laut Damaskus. Bahasa Inggris dan Perancis secara luas digunakan sebagai bahasa kedua, tetapi bahasa Inggris lebih sering digunakan (Ys.herbi, n.d.).

Dari pemaparan di atas, meskipun bahasa Arab tertulis sebagai bahasa resmi negara Suriah, namun warga Suriah lebih sering menggunakan bahasa Inggris dari bahasa Arab, serta lebih mengunggulkan bahasa di kalangan etnis masing-masing daerah. Peran bahasa Arab sebagai pemersatu umat di Suriah dirasa mengalami disfungsi karena semakin hilang- 
nya komitmen persatuan dan kesatuan bangsa dan lebih mementingkan kepentingan etnis, kelompok, sekte, atau agama tertentu. Konflik antara Sunni dan Syiah, ataupun antara masyarakat sipil dan pemerintah selalu memicu pada peperangan dan pertumpahan darah yang belum bisa menemukan titik temu perdamaian sampai sekarang.

\section{Revitalisasi Peran Bahasa Arab untuk Mengatasi Konflik dalam Perspektif Multikultural}

Kata revitalisasi berarti menjadikan sesuatu atau perbuatan untuk menjadi vital. Kata vital sendiri memiliki arti sangat penting atau sangat diperlukan sekali untuk kehidupan (Anonim, 2015) Revitalisasi peran bahasa Arab dapat dimaknai sebagai upaya untuk mengembalikan peran bahasa Arab sebagai bahasa komunikasi yang efektif dalam meredam konflik di negara-negara Arab yang sedang berseteru. Tujuan utama revitalisasi peran bahasa Arab dalam konteks ini meliputi; (1) mengembalikan peran bahasa Arab sebagai bahasa pemersatu bangsa-bangsa Arab; (2) bahasa Arab dapat menjadi mediator untuk menyelesaikan konflik; (3) bahasa Arab dapat mewujudkan perdamaian di negara-negara Arab dengan kesadaran masyarakatnya yang multikultural.

Sejumlah tahapan upaya yang dapat dilakukan dalam proses revitalisasi peran bahasa Arab untuk mengatasi konflik dalam perspektif multikultural adalah; 1) menegaskan kembali tentang urgensi bahasa Arab sebagai bahasa Agama Islam yang mempunyai substansi penting dalam mengajarkan nilai-nilai kebaikan terutama tentang kesadaran multikultural yang termaktub dalam Alquran dan sunnah; (2) mendeklarasikan kembali tentang posisi bahasa Arab sebagai bahasa resmi negara yang harus digunakan sesuai dengan ketentuan bahasa Arab fusha secara massif dan konsekuen; (3) memperkuat komitmen berbahasa Arab dengan baik dan benar dalam berkomunikasi yang disesuaikan dengan etika dan moral; (4) mengutamakan penggunaan bahasa Arab dalam berbagai forum pendidikan dan pemerintahan tanpa mengesampingkan penggunaan bahasa asing Inggris atau Perancis; (5) menggunakan bahasa Arab fusha secara lisan maupun tulisan agar meminimalisir penggunaan bahasa Arab 'amiyyah yang berbeda dari suatu negara dan antar negara. Sehingga bahasa Arab menjadi satu kepahaman dari negara-negara yang berbahasa Arab untuk dapat mencegah konflik atau mendamaikannya.

Sudah saatnya di era kemajuan teknologi saat ini, di saat umat manusia berada dalam perkembangan intelektualitas dan sangat menjunjung tinggi nilai-nilai kemanusiaan, pertikaian di negara Arab khususnya di Timur Tengah dapat dihentikan. Setelah melalui proses revitalisasi, bahasa Arab diharapkan dapat benar-benar berperan sebagai proteksi perdamaian dan pengubah situasi peperangan menjadi persatuan. Umat berbahasa yang memiliki kesadaran tentang multikultural sebagai sebuah given atau pemberian dari Tuhan, akan menjadikan keragaman budaya, suku, dan agama sebagai asset berharga, kekayaan bangsa dan kekuatan untuk mewujudkan kehidupan yang toleran dan harmonis.

\section{SIMPULAN}

Masyarakat Arab yang multikultur dan heterogen beruntung memiliki bahasa Arab sebagai simbol kesatuan. Namun pada kenyataannya, masih ada negara Arab yang bertikai dalam perang saudara berkepanjangan karena perbedaan sekte keagamaan sebagaimana yang terjadi di negara Lebanon dan Suriah. Atas dasar hal ini, maka perlu dilakukan revitalisasi peran bahasa Arab untuk mengatasi konflik dalam perspektif multikultural.

Tahapan-tahapan revitalisasinya adalah; (1) menegaskan kembali urgensi bahasa Arab sebagai bahasa Agama Islam yang mempunyai substansi penting dalam mengajarkan nilai-nilai kebaikan terutama tentang kesadaran multikultural yang termaktub dalam Alquran dan sunnah; (2) mendeklarasikan kembali tentang posisi bahasa Arab sebagai bahasa resmi negara yang harus digunakan sesuai dengan ketentuan bahasa Arab fusha secara massif dan konsekuen; (3) memperkuat komitmen berbahasa Arab dengan baik dan benar dalam berkomunikasi yang disesuaikan dengan etika dan moral; (4) mengutamakan penggunaan bahasa Arab dalam berbagai forum pendidikan dan pemerintahan tanpa mengesampingkan penggunaan bahasa asing Inggris atau Perancis; (5) menggunakan bahasa Arab fusha secara lisan maupun tulisan agar meminimalisir penggunaan bahasa Arab 'amiyyah yang berbeda dari suatu negara dan antar negara. 
Kesadaran multikultural memberikan pemahaman kepada umat manusia untuk berperilaku humanis dan toleran serta menganggap keberagaman sebagai suatu keniscayaan atau bahkan kepastian yang tidak dapat dihindari. Di sini, peran bahasa Arab menjadi vital untuk dijadikan alat ketika berdialog, berunding, berdiskusi, dan bermusyawarah dalam menghadapi masalah perbedaan. Sehingga bahasa Arab dapat menjembatani berbagai konflik di negara-negara Arab yang masyarakatnya multikultur

\section{DAFTAR PUSTAKA}

Abusyairi, K. (2013). Pembelajaran bahasa dengan pendekatan budaya. Dinamika Ilmu, 13(2). https://doi.org/10.21093/di.v13i2.276

Anonim. (n.d.). Sekilas tentang Lebanon. Retrieved from http://dwpkbribeirut.tripod.com/id2.html

Anonim. (2013). Pentingnya bahasa arab di era globalisasi. Retrieved from https://elfaiznamjha.wordpress.com/201 3/09/17/pentingnya-bahasa-arab-di-eraglobalisasi/

Anonim. (2015). Aktualisasi dan Revitalisasi Pancasila. Retrieved from http://paridabdulloh.blogspot.com/2015/ 02/akualisasi-dan-revitalisasipancasila.html

Baidhawy, Z. (2005). Pendidikan agama berwawasan multikultural. Jakarta: Erlangga.

Banks, J. A. (2007). Educating citizens in a multicultural society. New York: Teacher College Press.

Boullata, I. J. (2001). Trends and issues in contemporary arab thought. (Dekonstruksi tradisi, gelegar pemikiran Arab Islam). (I. Khoiri, Trans.). Yogyakarta: LKIS.

Carpenter, T. G. (2013). Tangled web: the Syrian civil war and its implications. Mediterranean Quarterly, 24(1), 1-11. https://doi.org/10.1215/104745522018988
Chaer, A., \& Agustina, L. (2004).

Sosiolinguistik: perkenalan awal. Jakarta: Rineka Cipta.

Fox, J. (2002). Defining religion's role in society. In Ethnoreligious conflict in late twntieth century (p. 26). A General Theory. Lexington Books.

Hambal, A. 'Ibn. (n.d.). Musnad al-Imam Ahmad ibn Hanbal (Vol. VI). Kairo: Mu'assasah Qurtubah.

Koentjaraningrat. (2009). Pengantar ilmu antropologi. Jakarta: Rineka Cipta.

Manshur, I. (2010). Sekilas mengenal negara Suriah (Syria) dan jumlah penduduknya. Retrieved from http://www.muslimedianews.com/2014/ 03/sekilas-mengenal-negara-suriahsyria.html\#ixzz5eWh568HW

Mantra, I. B. (2008). Filsafat penelitian dan metode penelitian sosial. Yogyakarta: Pustaka Pelajar.

Mu'min, M. (2016). Pendidikan Islam multikultural dalam perspektif filosofis. FENOMENA, 8(1), 71-90. https://doi.org/10.21093/fj.v8i1.487

Muhadjir, N. (1998). Metode penelitian kualitatif. Yogyakarta: Rake Sarasin.

Mujib, A. (2009). Hubungan bahasa dan kebudayaan (perspektif sosiolinguistik) hubungan bahasa dan kebudayaan (perspektif sosiolinguistik). Adabiyyāt: Jurnal Bahasa dan Sastra, 8(1), 141154. https://doi.org/10.14421/ajbs.2009.\%x

Raharja, S. (2010). Mengkreasi pendidikan multikultural di sekolah dengan menerapkan manajemen mutu sekolah secara total. Jurnal Manajemen Pendidikan: Jurnal Ilmiah Adminstrasi, Manajemen Dan Kepemimpinan Pendidikan, VI(2).

Saripedia. Jumlah penutur bahasa arab di dunia (2011). Retrieved from https://saripedia.wordpress.com/tag/juml ah-penutur-bahasa-arab-di-dunia/ 
Shawish, H. (2010). Kampanye bahasa Arab di Lebanon. BBC News Indonesia. Retrieved from https://www.bbc.com/indonesia/majalah/ 2010/06/100617_lebanon

Shihab, M. Q. (2002). Tafsir Al-Misbah, pesan dan keserasian Al-Qur'an (Vol. 1). Jakarta: Lentera Hati.

Suparman, H. (2017). Multikultural dalam perspektif Alquran. AL QUDS : Jurnal Studi Alquran dan Hadis, 1(2), 185-204. https://doi.org/10.29240/alquds.v1i2.250

Sutardi, T. (2007). Antropologi: mengungkap keragaman budaya. Bandung: PT Setia Purna Inves.

Wahab, M. A. (2014). Peran bahasa arab dalam pengembangan ilmu dan peradaban Islam. ARABIYAT: Jurnal Pendidikan Bahasa Arab Dan Kebahasaaraban, 1(1).

Wekke, I. S. (2017a). Konflik kebahasaan Timur Tengah. Retrieved from http://ismes.net/2017/06/konflikkebahasaan-timur-tengah/

Wekke, I. S. (2017b). Pembelajaran bahasa arab berbasis multikultural. Yogyakarta: Gawe Buku.

Wekke, I. S., \& Lubis, M. A. (2008). A Multicultural Approach in Arabic Language Teaching: Creating Equality at Indonesian Pesantren Classroom Life. SOSIOHUMANIKA, 1(2).

Ys.herbi. Bendera Juang: Profil: Informasi tentang Negara Suriah [Lengkap], Bendera Juang §. Retrieved from https://benderajuang.blogspot.com/2018/ 10/suriah.html

Zaenuddin, R. (2005). Metodologi dan strategi alternatif pembelajaran bahasa Arab. Yogyakarta: Pustaka Rihlah Group. 